\title{
Structuring and creating alternatives for the eggplant loss problem using the value-focused thinking methodology
}

Volumen 20 No (2). Julio-Diciembre 2020. Pág. 53-71

ISSN: 0121-1048 IMPRESO ISSN: 2422-3220 EN LÍNEA

\author{
Larreta Ramírez, \\ Elsa Verónica \\ Universidad Autónoma \\ de Occidente. Economic \\ and Management \\ Sciences Department. \\ Blvd. Lola Beltrán $s / n, 4$ \\ de Marzo, cp. 80054. \\ Culiacan, Sinaloa, \\ Mexico.
}

veronica.larreta@udo.mx

\author{
Gastélum Chavira, \\ Diego Alonso* \\ Universidad Autónoma de \\ Occidente. Economic and \\ Management Sciences \\ Department. Blvd. Lola \\ Beltrán s/n, 4 de Marzo, \\ cp. 80054. Culiacan, \\ Sinaloa, Mexico. \\ diego.gastelum@udo.mx \\ *Corresponding author
}

\author{
Leyva López, Juan \\ Carlos \\ Universidad Autónoma de \\ Occidente. Economic and \\ Management Sciences \\ Department. Blvd. Lola \\ Beltrán s/n, 4 de Marzo, \\ cp. 80054. Culiacan, \\ Sinaloa, Mexico. \\ juan.leyva@udo.mx
}

\author{
Ahumada \\ Valenzuela, Omar \\ Universidad Autónoma de \\ Occidente. Engineering \\ Sciences Department. \\ Blvd. Lola Beltrán s/n, 4 \\ de Marzo, cp. 80054. \\ Culiacan, Sinaloa, Mexico. \\ omar.ahumada@udo.mx
}

\begin{abstract}
Eggplants are a short shelf-life vegetable, whose exports generate a significant income for Mexican horticultural companies. However, when the market's price is down or the product quality does not fulfill the market's requirements, eggplants are not exported, and given a lack of demand in the domestic market not all the crops can be commercialized. This situation generates financial problems for companies, unemployment for people, and environmental problems, among others. To reduce eggplant losses, it is necessary to understand the issues, and the structure of the problem, to generate solution alternatives. In this work, the Value-Focused Thinking (VFT) methodology was applied in a horticultural farm in Sinaloa, Mexico, to obtain values from a decision-maker to structure the eggplant's loss problem, its objectives, and generating solution alternatives. This article presents a structured problem of eggplant postharvest loss, which includes one strategic objective, five fundamental objectives, nine means-ends objectives, and twentyseven solution alternatives such as applying protected agriculture technology, selling waste as food for livestock, and designing a new product based on eggplant. Through the results of the application of VFT methodology, the decisionmaker understood the eggplant loss problem and its value, which will be reflected in benefits for the horticultural farm.
\end{abstract}

Keywords: Eggplant loss, problem structuring, creating alternatives, value-focused thinking.

JEL codes: D46, D81

\footnotetext{
• Citar: Larreta Ramírez, Elsa Verónica, Gastélum Chavira, Diego Alonso, Leyva López, Juan Carlos, Ahumada Valenzuela, Omar (2020). Structuring and creating alternatives for the eggplant loss problem using the value-focused thinking methodology. Inquietud Empresarial, 20(2), 53-71
} 


\title{
Estructurando y creando alternativas para el problema de desperdicio de berenjenas utilizando la metodología de pensamiento enfocado en el valor
}

\begin{abstract}
Resumen
La berenjena es un vegetal de corta vida útil cuya exportación en México genera ingresos significativos para las empresas hortícolas. Sin embargo, cuando el precio de mercado es bajo, o su calidad no cumple sus requisitos, la berenjena no se exporta, y el mercado interno es muy reducido. Esta situación genera problemas financieros para las empresas, desempleo y problemas ambientales. Para reducir la pérdida de berenjenas es necesario comprender los elementos que rodean el problema, estructurarlo y generar alternativas de solución. En este trabajo, se aplicó la metodología del Pensamiento Enfocado en el Valor (VFT) en una empresa hortícola en Sinaloa, México; para obtener los valores de un tomador de decisiones para estructurar el problema de pérdida de berenjenas, obtener los objetivos de la empresa y generar alternativas de solución. Este artículo presenta el problema estructurado, incluyendo un objetivo estratégico, cinco objetivos fundamentales, nueve objetivos medios y veintisiete alternativas de solución, tales como la aplicación de tecnología agrícola protegida, venta de desperdicios como alimento para ganado y diseño de un nuevo producto. A través de VFT, el tomador de decisiones comprendió mejor el problema de pérdida de berenjenas y su valor, lo cual beneficiará a la empresa.
\end{abstract}

Palabras clave: Desperdicio de berenjena, estructuración de problemas, creación de alternativas, pensamiento enfocado en el valor.

Códigos JEL: D46, D81

\section{INTRODUCTION}

Annually around 1.3 billion tons of food produced worldwide destined for human consumption become food loss or food waste (FAO, 2011). These losses occur throughout all the supply chain, from initial production in the fields to final consumption. From the growers' perspective, this situation represents a waste of natural resources like water, land, energy, and the inputs used in production, including labor, which finally leads to financial loss. But, for consumers, those losses affect food security, increasing the prices of food.

For the Food and Agriculture Organization of the United Nations (FAO), food losses are defined as reducing edible food mass for human consumption, which occurs during production, harvest, postharvest, and processing phases. One of the highest generators of food losses in agriculture is the horticultural sector. Every year, around $11-48 \%$ of the total food production is lost before it reaches the consumer market. On the other hand, both retailers and consumers derive food waste by throwing perfectly edible foodstuffs into the trash. Food loss and waste can reach around $36-55 \%$ of fruit and vegetables, $32-60 \%$ of roots and tubers, $29-50 \%$ of fish and seafood, $20-26 \%$ of meat, $19-35 \%$ of cereals, and $18-$ $29 \%$ of oilseeds and pulses (FAO, 2011).

In low and middle/income countries, the causes of food losses and waste are mainly connected to financial, infrastructure, 
Larreta Ramírez, Elsa Verónica, Gastélum Chavira, Diego Alonso, Leyva López, Juan Carlos, Ahumada Valenzuela, Omar

climatic phenomena, packaging, and marketing systems (FAO, 2011). In middle/high-income countries, the causes are mostly related to consumer behavior and a lack of coordination between the supply chain actors. Other factors of this situation are sales agreements between farmers and buyers, because products are discarded when the quality standards demanded by the market are not met.

For countries, the reduction of food loss has benefits both on socioeconomic and environmental terms. It would increase producers' income by reducing costs for treatment and eliminating food loss, which would lead to cheaper food, allowing food security and nutrition for more people. In environmental terms, food loss reduction would decrease the inefficient use of energy, water, land, greenhouse gas emissions, and other damages caused by non-consumed food. By 2030, the United Nations aims to "halve per capita global food waste at the retail and consumer levels and reduce food losses along production and supply chains, including post-harvest losses" (UN, 2015). Thus, reduction of waste or loss of food is on the agendas of various agencies around the world, such as the Food and Agriculture Organization of the United Nations (FAO), the Department of Agriculture (USDA), and the Environmental Protection Agency (EPA) in the United States of America (USA); the European Commission (E.C.) in the European Union; the Secretary of Agriculture (SADER) in Mexico.

Mexico is a country with a population of 124.1 million (INEGI, 2015). In 2017, it produced 286 million tons of food, coming from agricultural $91.96 \%$, livestock $7.38 \%$, and fishing $0.73 \%$ (SADER, 2019). In 2018, the country was ranked as the fourth exporter of edible vegetables and certain roots and tubers globally, with 7,060,172 US thousand Dollars (ITC, 2019b). However, in Mexico, it is estimated that around $35 \%$ of the produced food is food loss or waste (CEC, 2019), which occur mostly in the first stages of the food supply chain. Several activities influence preharvest activities in the industrial, commercial, and institutional (ICI) production and consumption stages, and vice versa (CEC, 2017).

Sinaloa state, which is located in the northwest of the country, with a population of 2,966,321 (INEGI, 2015), it is one of the national leaders in producing and processing fresh food such as tomato, green beans, potato, cucumber, and eggplant, where most of its export production is targeted to the USA (SADER, 2019). Sinaloa's horticultural sector generates more than 150 thousand jobs, mostly migrant workers, and another 50 thousand temporary jobs for residents. This sector has a multiplier effect in other areas, such as services and supplies (e.g., seeds, fertilizers, and agrochemicals). However, out of the 11 million tons of its agri-food produced in Sinaloa, only 15\% receive added value through the agroindustry. It positions Sinaloa in the 22nd place of 32 in Mexico's agroindustry activity (GSS, 2017).

In 2017, Mexico exported 77,044.90 tons of eggplant with a value of USD 59,233,523, whose main target was the USA with $93.71 \%$ of the shipments to this country (Secretary of Economy, 2019). That year, the country produced 184,872 tons of eggplant, where Sinaloa produced $96.6 \%$ (SADER, 2019). Through a simple compute, it is clear that only $41.68 \%$ of eggplant production was exported. 
In 2018, Mexico was the third-place worldwide exporters of eggplant, representing $10.5 \%$ of world exports for this product (ITC, 2019a). It indicates that, for producers, it is attractively to export just the first-class eggplants in fresh, despite losing part of the second-class, which cannot all be allocated in the national market. Therefore, it is essential to generate alternative solutions to try to reduce eggplant losses.

Eggplant farming is complicated for producers, given their primary market is exporting to the U.S., which demands fresh products that are very perishable. Sinaloa's farmers face considerable challenges because this vegetable does not mature after being cut from a plant and interrupts its maturity process in an irreversible form. Moreover, it has a short shelf life even if it is cut in a nonmaturity stage; thus, it needs to be harvested and packaged in the field to reduce damages by handling and exposition to high temperatures.

Likewise, farmers must deal with several causes that lead to eggplant loss while it is on the field: climate, pests, and diseases of plants. Also, eggplant loss comes from poor harvesting practices by cutting, grading, transport, marketing, and wear unsuitable containers for its marketing. Eggplant losses have adverse economic, environmental, and social effects on the horticultural sector. When eggplant does not fulfill the target markets' quality standards or the price is low (making it unprofitable), farmers have problems maintaining their exports and face production and marketing costs. When it happens, decision-makers stop the eggplant harvesting process and have to store eggplants. Sometimes, the order is to pour eggplants into drains, open fields, or roadsides dumps, affecting the environment, since it attracts pests, also impacting gas emissions that contribute to global warming, climate change, food security, and exports. Eggplant losses also affect the work environment of agricultural workers seeking better salary opportunities and services.

When eggplant does not fulfill foreign market quality standards that reduce shipments abroad, it cannot be allocated in domestic markets since the Mexican population does not have a culture of eggplant consumption. These generate economic, social, and environmental problems for Sinaloa, mainly producers, farm employees, and their families. Thus, it is necessary to create solution alternatives to reduce food loss inside agricultural companies; due to the economic, social, and environmental impacts. The exportation of added value agri-food is an opportunity to increase the income of those who participate throughout the productive chain until the product is commercialized. Added value in agri-food products allows to extend shelf-life of the products, increment its commercial value, promoting the agroindustry, and transforming the products.

This work aims to present an application focused on structuring the eggplant loss problem in a horticultural farm and generate solution alternatives to reduce such loss. The farm has a representativity of $22 \%$ of the eggplant market shared in the port of Nogales, Arizona. In the application, the Value-Focused Thinking methodology (VFT) (Keeney, 1996) was used to structure such a problem and to generate a set of solution alternatives to reduce the eggplant loss. The rest of the document is structured as follows: Section 2 includes a brief literature review about food loss and problem structuring; Section 3 presents the VFT methodology; 
Section 4 presents the application of the methodology in the farm; finally, Section 5 is intended for conclusions.

\section{LITERATURE REVIEW}

Literature provides different strategies and opportunities to reduce loss or waste of vegetables, including eggplant: Hodges et al. (2011) presented a review comparing postharvest food losses and waste between developed and low-middle-income countries. Papargyropoulou, Lozano, Steinberger, Wright, \& Ujang (2014) affirm that for a more sustainable resolution of the food waste issue, the first step is to adopt a sustainable production and consumption approach, as well as tackle food surplus and waste in the global food supply chain. Likewise, Thyberg \& Tonjes (2016) studied the drivers of food waste and its implications for developing sustainable policies. Likewise, Redlingshöfer, Coudurier \& Georget (2017) affirm that, in France, food loss occurs at the upstream stages of supply chains where the role of such stages varies in each food sector. It is a complicated situation that affirms the authors because there is a wide variation of food loss and the food sectors and supply chains. In this paper, the authors present recommendations to quantify food loss at the upstream stages of supply chains, e.g., to include in the analysis of food loss and public and private stakeholders' expertise related to food sectors.

On the other hand, Beausang, Hall, \& Toma (2017) conducted semi-structured interviews with farmers in Scotland to gather information about the attitudes of farmers about food waste, including the quantity of food waste generated on farms, the causes, and treatments of food waste and strategies to reduce it. They identified that the roots of food waste include cosmetic specifications by retailers and a lack of processing facilities. In this case, the study reports that overproduction is not a cause for food loss. Finally, the authors suggest relaxing such cosmetic specifications and investing in processing facilities. Likewise, Wakiyama et al. (2019) examine edible food loss at the stage of vegetable production in Japan. They identified that a significant amount of vegetables is harvested but not delivered to markets. Among the reasons for food loss, the authors identified the overproduction, lowering demand, or nonstandard vegetables, i.e., cosmetic specifications. Also, the authors made a footprint analysis to identify where are the vegetable discarded in fields.

In a contribution, Principato, Ruini, Guidi \& Secondi (2019) report percentages of food loss and food waste in the value chain concerning pasta manufacturing. They present options that could be implemented to avoid food loss and food waste. Among these proposals, they proposed that the primary production stage, the crop straw, could be reused as a natural fertilizer or animal feed. In the wheat milling stage, food loss could also be used for animal feed or energy recovery. In the production stage, food loss could be donated to food banks or for composting. Finally, at the retail level, food waste could also be delivered to food banks or animal feed.

In the case of eggplant, Ghidelli, Mateos, Rojas-Argudo, \& Pérez-Gago (2014) analyzed the effect of a soy protein-based edible coating antioxidant activity to extend the shelf life of fresh-cut eggplant. Gallo et al. (2014) proposed a method to obtain anthocyanin extracted from eggplant shells. Meanwhile, Meyer, Bamshad, Fuller, \& Litt (2014) compared medical uses of eggplant and 
related Solanaceae in China, India, and the Philippines. Finally, Llave et al. (2016) proposed an approach to compute the evolution time of different variables, which allows the application of similar structural mechanics models in heating foods, such as drying and broiling of eggplant.

Similarly, as in food loss and food waste topics, the literature provides different approaches to solve decision problems. Among them is Value-Focused Thinking (VFT), a multi-attribute methodology proposed by Ralph Kenney (Keeney, 1996). It is about how values can be used to improve the decision-making process. In this process, a decision-maker or a set must express their values on aspects such as weights, objectives, and attributes. Values indicate what decisionmaker hopes to achieve by making the decision. They are the reason to spend any time thinking about the decision, principles used for evaluating the actual or potential consequences of the action, and the alternatives' inaction. VTF methodology provides a decision framework composed of the decision context and the fundamental objectives to define an appropriate set of alternatives for a decision situation.

Using the VFT methodology helps organize the values to understand their relationships and roles to facilitate their uses. The process of structuring values and developing objectives helps in a deeper and more accurate understanding of what decision-makers care of a given decision context (Keeney, 1996). However, due to a simple listing with objectives is shallow, it is necessary a clear structure in greater depth, and a sound conceptual base in developing objectives for strategic decision contexts.
In a decision context, identifying and structuring objectives are difficult tasks. It is because identification requires using meaningful creativity in discussions with decision-makers and stakeholders. The decision is often characterized by multiple objectives, which complex its structuring by the relations between them. In VFT methodology, according to (Keeney, 1996), an objective is a statement of something that one wants to strive towards and is characterized by three distinct features: a decision context, an object, and a direction of preference.

To structure a decision problem is necessary to distinguish two types of objectives: fundamental objectives and means-ends objectives, which are contextdependent. A fundamental objective characterizes an essential reason for interest in the decision situation. A means-ends objective concerns the degree of achievement of a fundamental objective. They are meansends to the achievement of the fundamental objectives. Thus, (Keeney, 1996) indicates it is crucial to identify, structure, analyze, and understand the objectives more thoroughly. It can be done by using appropriate strategies to stimulate the identification and choice of objectives. It should be measurable, operational, decomposable, nonredundant, concise, and understandable.

VFT methodology has been applied in different contexts to structure problems, identify objectives, and generate solution alternatives. For instance, in the environmental area: Mustajoki et al. (2011) applied VFT for sustainable use of the forests in Finnish Upper Lapland. Meanwhile, Alencar, Mota, \& Alencar (2011) conducted a study about the gypsum used in the construction sites in Brazil, and Karjalainen, 
Marttunen, Sarkki, \& Rytkönen (2013) developed an ecosystem service valuation to measure the environmental impact of restoration options for a regulated river in Finland. In other areas, VFT has been applied by Sheng, Siau, \& Nah (2010) to analyze the learning in the educational environment when mobile technology is used to support and improve education. Meanwhile, Keeney \& Von Winterfeldt (2010) performed a study to understand better terrorists' motivations and their reasons for selecting specific modes and targets of attack. Also, Selart \& Johansen (2011) performed a study about the impact of Value-Focused Thinking and AlternativeFocused Thinking methods. May, Dhillon, \& Caldeira (2013) defined value-based objectives for Enterprise Resource Planning (ERP) to minimize failure rates in three large European firms. Keeney (2013) identified, prioritized, and used multiple objectives on the problems for allocating funds to alleviate different homeland security hazards and evaluating potential customers for credit cards. Finally, Siau \& Ling (2017) studied the values of mobile applications for supporting collaboration among virtual team members.

\section{Methodology}

This case study's primary purpose was to structure the eggplant loss problem and create solution alternatives for its reduction in a farm. The study also aims to better understand this problem to the decisionmaker, given the lack of information about the real decision problem, and it could reduce food loss. The VFT methodology was used, whose typical application can be divided into the following six stages:

First stage: Semi-structured interviews. Here, the decision-makers and stakeholders participate in a set of semi-structured interviews. Questions are formulated to identify wish lists, problems, shortcomings, impacts, alternatives, consequences, goals, constraints, and strategic objectives related to the organization and its situation.

Second stage: Identification and definition of the problem. The problem is identified and defined with provided information in the previous stage and continuous communication with the decision-makers and stakeholders. It is the most important for the whole process; correct identification and structuring the problem will result in more assertive decision-making. If the problem is incorrectly identified and structured, the resulting solution will have limited or no value.

Third stage. Identifying preliminary means-ends and fundamental hierarchy objectives. Here, a set of activities are performed to identify the preliminary meansends objectives and fundamental hierarchy objectives. These activities include generating a list of objectives of the decisionmaker, checking for redundancy in the list of objectives, identifying the fundamental and means-ends objectives, defining the strategic objective, drawing a network diagram of objectives for a better understanding of them, analyzing the objectives generated with the decision-maker and stakeholders.

Fourth stage: Measuring the achievement of objectives. At this point, the measurements are defined to know the degree of achievement of an objective to become natural attributes, constructed, or proxy.

Fifth stage: Quantifying objectives. Here, it is necessary to compute the utility of each fundamental objective. Previously, each objective is required to obtain its weight and value ranges of each one of its attributes. To 
quantitatively represent the problem, the Multiple Attribute Utility Theory (MAUT) (Kenney \& Raiffa, 1976) approach, or another one, can be applied. MAUT is based-on the Utility Theory (Von Neumann \& Morgenstern, 1944)It allows modeling a decision problem mathematically using the attributes' values and considering the decision-maker's preferences (weights). MAUT is oriented to optimize (maximize) an additive function, namely utility function $u$ defined as $u\left(a_{i}\right)=w_{1} g_{1}+w_{2} g_{2}+. .+w_{k} g_{k}$ where $a_{i}$ is a decision alternative of a given set of alternatives $A=\left\{a_{1}, a_{2}, . ., a_{m}\right\} ; g$ is an attribute of a given set of attributes $G=\left\{g_{1}, g_{2}, . ., g_{k}\right\}, w$ is the associated weight to an attribute $W=\left\{w_{1}, w_{2}, . ., w_{k}\right\}$, and $k$ is the number of attributes of $G$, i.e. $k=|G|$. The values of each attribute are obtained from the organization's data and decisionmaker's knowledge. On the other hand, weights are obtained from decision-maker's preferences. There are different methods to obtain weights; however, it is desirable to choose compensatory methods as SMARTER and SMARTS due to the nature of MAUT.

SMARTER (Simple Multi-attribute Rating Technique Exploiting Ranks) is a method to obtain weights, which uses a Rank Order Centroid (ROC) table. It includes defined weights for a different number of attributes. These weights are generated using the equation presented in Edward \& Barron (1994):

$$
w_{k}=(1 / k) \sum_{i=k}^{K}(1 / i)
$$

where $K$ is the number of attributes and $w_{k}$ is the $w^{\text {th }}$ weight of attribute $k$. Thus, given a set of attributes, the decision-maker is asked to order such set, obtaining a ranking of attributes. Then, weights of them are obtained using the ranking and ROC table. A study on SMARTER's efficacy is available in Barron \& Barret (1996).

Sixth stage: Stimulating the creation of alternatives. In this last point, a set of alternatives is created to solve the problems of the organization. Different ideas to generate them are analyzing each objective separately, analyzing each pair of objectives, analyzing each group of three objectives, and analyzing which selected alternatives allow achieving the objectives. A study related to creating and generate alternatives is presented in Siebert \& Keeney (2015).

\section{RESULTS}

This section concerns a real case application of the Value-Focused Thinking methodology. Here, VFT was applied in a horticultural farm to solve the problem of eggplant loss. The section begins with a brief description of such a farm, and then it shows the results of the application of the VFT to structure the eggplant problem and generate alternative solutions.

\subsection{The farm and its context}

The farm is a significant producer and marketer of eggplant in Sinaloa, Mexico. It is located around $966 \mathrm{~km}$ from Nogales, Arizona, USA, which is its exportation port. The farm has 30 permanent employees and approximately 400 temporary employees for cutting work on the field and vegetable packaging. In 2016, the farm sowed 100 open field hectares of eggplant.

In Sinaloa, the open field eggplant planting season begins in September and, the season for cutting and packing is from November to June. The demand for eggplant 
increases between January and March due to the Lenten season.

The farm exports most of its production through distributors, its main customers. Nowadays, the farm has between $15 \%$ and $19 \%$ market share of eggplant in the port of Nogales, Arizona. However, when the eggplant's price is low in the USA, the farm's decision-makers do not to send the product because it is not profitable. The same happens when eggplant's quality does not fulfill the USA market's requirements. These situations generate problems for the farm, such as costs in the production process, loss of loyalty of employees who harvest and pack the eggplant, bail insurance retention, or fines by generating environmental problems when decision-makers decide not to harvest the eggplant, among others.

Owners of the farm wish to increase market share and diversify their products based on eggplants, either fresh or processed. Besides, they wish to open new domestic markets for processed eggplant by the export barriers for processed products in the USA.

The VFT methodology was used to structure such a problem and generating alternative solutions. It considering the farm's eggplant loss problem and decisionmakers' wishes. The application is next presented.

\subsection{The application of the VFT methodology}

As mentioned in Section 3, the VFT methodology can be divided into six stages. During its use on the farm, eight meetings were performed with the decision-make. The methodology was applied in seven months due to the schedule of the decision-maker: negotiations, planning of planting with the distributors, supervising activities for sowing, harvesting, packaging, transportation, and commercialization of eggplant.

In the first stage of VFT, semi-structured interviews with decision-makers and stakeholders, the interviews were applied to the farm's decision-maker. Later, with the gathered information, a general description of the farm and its status was redacted in a document. Then decision-maker corroborated the information of the document. The first semi-structured interview included some of the following questions: What are the farm's objectives in the short and long term? Why do you consider they are important? What are the problems and weaknesses of the farm? What are the effects of these problems and weaknesses on the farm? Why is it important to solve them? In your opinion, why are these problems presented? How can you solve them? What are the impacts of these problems on the economic, social, and environmental aspects? From your point of view, which are the consequences of continuing with this situation? Nowadays, how have you faced these consequences? and so on. Information presented in subsection 4.1 about the farm and its context is part of the first stage's obtained results.

In the second stage, identification and definition of the problem, two related problems were identified from the interviews with the decision-maker. The first one corresponds to the lack of personnel to work on the field for tasks such as sowing, cutting, harvesting, and packing. The second problem is related to non-marketed eggplant when it does not fulfill quality specifications required by the target export market: size, color, form, or texture; or when its price is low in such a market. Sometimes, the lack of quality is 
caused by the first problem, i.e., when the lack of staff is presented; eggplant is not cut on time; e.g., in the 2016-2017 horticultural season, a lack of staff, generated between 30 and $35 \%$ loss of production. This production was converted to loss by throwing it on the open field and used as food for cattle, despite being optimal for human consumption. According to the decision-maker, the farm cannot efficiently commercialize this secondclass product in the domestic market because this vegetable is practically not consumed by the Mexican population. Thus, it is converted to loss, and the farm reduces its incomes. Although the lack of labor is essential, it is a social problem out of this work's scope. Hence, the second problem was chosen to structure it and create solution alternatives.

Suppose the farm solved its eggplant loss problem and became environmentally responsible. In that case, it can recover money from a guarantee bond refund, which is paid at the beginning of the agricultural season. This guarantee bond covers costs when, at the end of the season, the farm does not cut its production or does not clean its hectares. In this situation, the bond is used for cleaning costs of these hectares, thereby avoiding phytosanitary problems such as pests and environmental problems.

According to the decision-maker, if the problem continues in the farm, its economic capacity will decrease due to the high level of uncertainty. For this, the decision-maker has considered reducing the number of hectares to crop in the subsequent agricultural cycles. However, this decision is conditioned by volume commitments made with distributors from the USA. Moreover, if the decisionmaker reduces eggplant production, there exists the possibility that distributors look for other eggplant suppliers to meet market demand; thus, the farm could reduce its market share.

In the third stage of VFT, identifying preliminary means-ends objectives and fundamental hierarchy objectives, by using the information from previous stages and new meetings with the decision-maker, in this stage, a set of fundamental objectives $A$ and means-ends objectives $A$ 'were defined. A task to eliminate redundancy and the relations between the objectives was performed to generate a list with them. After that, a hierarchy of preliminary objectives was performed. This hierarchy of objectives was shown to the decision-maker to be analyzed, modified, and accepted. Once the set of objectives and its hierarchy were accepted, the orientation of maximizing or minimize for each objective $a_{i} \in A ; a_{i}^{j} \in A^{\prime} ; i=1, . ., m ; j=1, . ., n \quad$ was $\quad$ set. Table 1 shows the hierarchical structure of the objectives of the horticultural farm.

As mentioned in Section 3, to have a better understanding of the fundamental and means-ends objectives, it is recommended to draw the objectives in a network diagram to show the relations between them. This network helps to understand the problem and suggests alternatives that may be useful. To accomplish this step, two meetings with the decision-maker were necessary. The output of this stage was a clear structuring of the problem, a list of objectives for the current situation of the organization, and the network diagram of the objectives, which is presented in Appendix A.

In the fourth stage, measuring the achievement of objectives, the decisionmaker set that the overall strategic objective is to maximize the farm's economic benefit. This strategic objective was divided into five 
fundamental objectives $a_{i} \in A ; i=1, . .5$ -

Overhead costs, Eggplant yield, Economic loss from eggplant depletion, Performance in eggplant packaging, and Sales- most of them, including means-ends objectives $a_{i}^{j} \in A^{\prime} ; i=1, . ., 5 ; j=1, . ., n$.

TABLE 1. THE HIERARCHICAL STRUCTURE OF THE OBJECTIVES

\begin{tabular}{|c|c|}
\hline Objective & $\begin{array}{l}\text { Type of } \\
\text { objective }\end{array}$ \\
\hline Maximize the economic benefit & Strategic \\
\hline - Minimize overhead costs & $\begin{array}{l}\text { Fundame } \\
\text { ntal }\end{array}$ \\
\hline - Minimize production costs & $\begin{array}{l}\text { Means- } \\
\text { ends }\end{array}$ \\
\hline - Minimize costs in interest rates & $\begin{array}{l}\text { Means- } \\
\text { ends }\end{array}$ \\
\hline - Maximize eggplant yield & $\begin{array}{l}\text { Fundame } \\
\text { ntal }\end{array}$ \\
\hline - Maximize seedling greenhouse yield & $\begin{array}{l}\text { Means- } \\
\text { ends }\end{array}$ \\
\hline $\begin{array}{l}\text { - Minimize lost seedling by transplant to } \\
\text { the field }\end{array}$ & $\begin{array}{l}\text { Means- } \\
\text { ends }\end{array}$ \\
\hline $\begin{array}{l}\text { - Minimize economic loss from eggplant } \\
\text { depletion }\end{array}$ & $\begin{array}{l}\text { Fundame } \\
\text { ntal }\end{array}$ \\
\hline - Maximize use of depletion & $\begin{array}{l}\text { Means- } \\
\text { ends }\end{array}$ \\
\hline $\begin{array}{l}\text { - Maximize performance in eggplant } \\
\text { packaging }\end{array}$ & $\begin{array}{l}\text { Fundame } \\
\text { ntal }\end{array}$ \\
\hline $\begin{array}{l}\text { - Minimize depletion during the } \\
\text { packaging process }\end{array}$ & $\begin{array}{l}\text { Means- } \\
\text { ends }\end{array}$ \\
\hline - Maximize workforce performance & $\begin{array}{l}\text { Means- } \\
\text { ends }\end{array}$ \\
\hline - Maximize sales & $\begin{array}{l}\text { Fundame } \\
\text { ntal }\end{array}$ \\
\hline - Maximize market share & $\begin{array}{l}\text { Means- } \\
\text { ends }\end{array}$ \\
\hline $\begin{array}{l}\text { - Minimize the difference between } \\
\text { market and distributor prices }\end{array}$ & $\begin{array}{l}\text { Means- } \\
\text { ends }\end{array}$ \\
\hline
\end{tabular}

Source: Own elaboration.

After that, in the fifth stage, quantifying objectives, an elicitation procedure was conducted with the decision-maker to describe the attributes, their measurement ranges, and the quantification of the objectives to construct a value model. These elements allowed to clarify, discover the objectives, and facilitate decision making. For each means-ends objective $a_{i}^{j}$, it is necessary to specify an attribute $t_{i}^{j} \in T ; i=1, . ., 5 ; j=1, \ldots n$; to measure the degree to which each objective $a_{i}^{j}$ is achieved. Each attribute $t_{i}^{j}$ explains what the objective $a_{i}^{j}$ is meant to address. Below a brief description of each fundamental objective $a_{i} \in A ; i=1, . .5$ is presented, including the attributes $t_{i}^{j}$ associated with each means-ends objective $a_{i}^{j}$ :

Minimize overhead cost. This fundamental objective $a_{1} \in A$ is composed of two means-ends objectives: minimize production costs $a_{1}^{1} \in A^{\prime}$ and minimize costs in interest rates $a_{1}^{2} \in A^{\prime}$. These means-ends objectives were measured the attributes production costs $t_{1}^{1} \in T$ and cost of interest rates $t_{1}^{2} \in T$, both to with minimization orientation. Production cost attribute is related to costs per packed box expressed in U.S. Dollars, where the best cost is around $\$ 4.10$ USD per each one, and the worst cost is close to \$7.18 USD. On the other hand, the attribute cost in interest rates concerns the cost of loans with banks, suppliers, and distributors. Therefore, the overhead cost objective $t_{1}^{2}$ is one of the most important because it impacts the farm's activities.

Maximize eggplant yield. This fundamental objective $a_{2} \in A$ has associated two means-ends objectives: maximize seedling greenhouse yield $a_{2}^{1} \in A^{\prime}$ and minimize lost seedling by transplant to the field $a_{2}^{2} \in A^{\prime}$. Here, the seedling greenhouse yield $t_{2}^{1} \in T$ and lost seedling by transplant to the field $t_{2}^{2} \in T$ attributes were defined to 
measure the performance of each means-ends objective. The first attribute $t_{2}^{1}$ corresponds to seedling units obtained between seed units planted, where the best performance is $95 \%$, and the worst performance is $80 \%$ of the total seedling in the greenhouse. The second attribute $t_{2}^{2}$ refers to seedling by transplant to the field, where its best performance is $2 \%$ loss per transplant, and the worst is $10 \%$. Both objectives are important because they allow obtaining greater yield in the eggplant, which has high costs of cultivation and the factors that negatively affect the plant when the sowing process is carried out.

Minimize economic loss from eggplant depletion. This fundamental objective $a_{3} \in A$ has associated the mean-and objective: maximize the use of depletion $a_{3}^{1} \in A^{\prime}$, measured by the attribute use of depletion $t_{3}^{1} \in T$. This attribute is related to the tons used depletion between the total depletion. The best situation is to take advantage of $100 \%$ of the depletion of eggplant, and the worst is not to take advantage of that. During the agricultural season, there are significant quantities of eggplant depletion; this is presented during the cutting, transport, and packaging process, representing economic losses for the farm.

Maximize performance in eggplant packaging. This fundamental objective $a_{4} \in A$ is composed of the means-ends objectives: minimize depletion during the packaging process $a_{4}^{1} \in A^{\prime}$ and maximize workforce performance $a_{4}^{2} \in A^{\prime}$, measured by attributes depletion during the packaging process $t_{4}^{1} \in T$ and workforce performance $t_{4}^{2} \in T$. The first attribute $t_{4}^{1}$ is related to eggplant damaged by poor handling between eggplant boxes quality export per 100, where the best performance is $0 \%$, and the worst is $5 \%$. The second attribute $t_{4}^{2}$ refers to the number of packed boxes per hour done by each worker, where the best performance is 25 boxes, and the worst is 15 boxes. These attributes contribute to maximizing eggplant packaging performance because eggplant is a very perishable vegetable, and it is necessary to take care of its handling and exhibition to high temperatures.

Maximize sales. This fundamental objective $a_{5} \in A$ has defined two means-ends objectives: Maximize market share $a_{5}^{1} \in A^{\prime}$ and minimize the difference in USD between the price in the market and the distributor's purchase price $a_{5}^{2} \in A^{\prime}$. The first one is measured by attribute market share $t_{5}^{1} \in T$ and the second one by the attribute difference between market and distributor prices $t_{5}^{2} \in T$. The market share attribute $t_{5}^{1}$ is obtained by dividing the total sales of the farm by the total market value of eggplant, and then, it is multiplied per 100. The best market share is $35 \%$, and the worst is $20 \%$. The second attribute $t_{5}^{2}$ is obtained from the difference between the price in USD of eggplant set by the distributor concerning eggplant price in the market. The best price is 1 dollar above the market price, and the worst is 2 dollars below to such price.

Each attribute was analyzed in conjunction with its fundamental objective to organize them in a relation hierarchy. Table 2 shows the attributes described 
previously, including their ranges of worst and best levels.

Once the attributes were defined, the weights of each fundamental objective were obtained according to the decision-maker preferences. The decision-maker was asked to compare a swing between the fundamental objectives, which classified the swings in order of importance. In this case, the number representing relative importance was obtained through the Rank Order Centroid (ROC) table of the SMARTER method (Edwards \& Barron, 1994). Weights placed in descending order of the fundamental objectives were: Overhead costs 0.4567, Eggplant yield 0.2567, Sales 0.1567, Economic loss from eggplant depletion 0.0900, Performance in eggplant packaging 0.0400 . The weight's values allow knowing the intensity of importance among the fundamental objectives.

TABLE 2. ATTRIBUTES FOR EACH MEANS-ENDS OBJECTIVE

\begin{tabular}{|c|c|c|c|c|}
\hline $\begin{array}{l}\text { Fundamental } \\
\text { objective }\end{array}$ & Means-ends objective & Attribute & $\begin{array}{l}\text { Worst } \\
\text { level }\end{array}$ & Best level \\
\hline \multirow[t]{2}{*}{$\begin{array}{l}\text { Minimize } \\
\text { overhead costs }\end{array}$} & Minimize production costs & $\begin{array}{l}\text { Production costs (per box packed in } \\
\text { U.S. Dollars). }\end{array}$ & 4.10 & $\$ 7.18$ \\
\hline & Minimize costs in interest rates & $\begin{array}{l}\text { Costs in interest rates (suppliers, } \\
\text { banks in pesos). }\end{array}$ & $13 \%$ & $5 \%$ \\
\hline \multirow[t]{2}{*}{$\begin{array}{l}\text { Maximize } \\
\text { eggplant yield }\end{array}$} & Maximize seedling greenhouse yield & $\begin{array}{l}\text { Seedling greenhouse yield (seedling } \\
\text { units obtained /seed units seeded). }\end{array}$ & $80 \%$ & $95 \%$ \\
\hline & $\begin{array}{l}\text { Minimize lost seedling by transplant to } \\
\text { the field }\end{array}$ & $\begin{array}{l}\text { Lost seedling by transplant to the } \\
\text { field (lost seedling / transplanted } \\
\text { seedling). }\end{array}$ & $10 \%$ & $2 \%$ \\
\hline $\begin{array}{l}\text { Minimize } \\
\text { economic loss } \\
\text { from eggplant } \\
\text { depletion }\end{array}$ & Maximize use of depletion & $\begin{array}{l}\text { Use of depletion (tons used /total } \\
\text { depletion). }\end{array}$ & $0 \%$ & $100 \%$ \\
\hline \multirow[t]{2}{*}{$\begin{array}{l}\text { Maximize } \\
\text { performance in } \\
\text { eggplant } \\
\text { packaging }\end{array}$} & $\begin{array}{l}\text { Minimize depletion during the packing } \\
\text { process }\end{array}$ & $\begin{array}{l}\text { Depletion during the packing process } \\
\text { (eggplant damaged by weak } \\
\text { handling/eggplant boxes quality } \\
\text { export *100). }\end{array}$ & $5 \%$ & $0 \%$ \\
\hline & Maximize workforce performance & $\begin{array}{l}\text { Workforce performance (number of } \\
\text { packed boxes /hours). }\end{array}$ & 15 & 25 \\
\hline \multirow[t]{2}{*}{ Maximize sales } & Maximize market share & $\begin{array}{l}\text { Market share (total sales of the farm / } \\
\text { total market value of eggplant) }{ }^{*} 100 \text {. }\end{array}$ & $20 \%$ & $35 \%$ \\
\hline & $\begin{array}{l}\text { Minimize the difference in USD between } \\
\text { the price in the market and the purchase } \\
\text { price of the distributor }\end{array}$ & $\begin{array}{l}\text { The difference in USD between the } \\
\text { price in the market and the purchase } \\
\text { price of the distributor (price in the } \\
\text { market - price set by the distributor). }\end{array}$ & 2 & 1 \\
\hline
\end{tabular}

Source: Own elaboration.

Usually, the next step is to compute a utility function using the obtained weights. Still, at this point, the decision-maker wanted to include other criteria related to the feasibility of achieving these objectives. In practice, this situation is typical because decision-makers learn about the problem during its structuring, and their preferences and values could change. Thus, the decisionmaker was asked about the feasibility of achieving the objectives. For this, a set of criteria $G=\{$ Technical, Economic, Operative, 
Temporary\} was defined by an elicitation process with the decision-maker. These criteria are classical elements considered in decision making in organizations. Even the criteria were defined and valued for this specific situation; they can be extrapolated to other farms and organizations of other sectors. Also, additional criteria can be defined following the recommendations presented in Roy \& Bouyssou (1993). In this case, the technical criterion corresponds to each fundamental objective's feasibility concerning the farm's technical equipment and facilities. The economic criterion is related to the economic capacity of the farm to reach every fundamental objective. The operative criterion was defined to evaluate the feasibility grade to achieve the fundamental objectives from an organizational perspective, e.g., knowledge, amount, and staff availability. Finally, the temporary criterion is related to the time to reach each fundamental objective. Each criterion was defined on an ordinal scale: Highly feasible (5), Very feasible (4), Feasible (3), Bit feasible (2), and Not feasible (1). The decision-maker made his judgment about the feasibility of achieving these objectives using such criteria. Table 3 shows each fundamental objective's performance, including the weights of each criterion obtained with the SMARTS method (Edwards \& Barron, 1994).

Next, a ranking of fundamental objectives was obtained using data from Table 4: Eggplant yield $\succ$ Overhead cost $\succ$ Economic loss from eggplant depletion $\succ$ Performance in eggplant packaging $\succ$ Sales. The symbol $\succ$ means "preferred to."

Finally, in the sixth stage, stimulating the creation of alternatives, each fundamental objective was analyzed separately; then, the analysis was a pairwise comparison between them; then, a tripartite comparison, etc. Table 5 shows the list of solution alternatives focused on to increase the economic benefit of the farm and reduce the problem of eggplant loss.

TABLE 3. PERFORMANCE OF EACH FUNDAMENTAL OBJECTIVE INCLUDING THE WEIGHTS OF EACH CRITERION

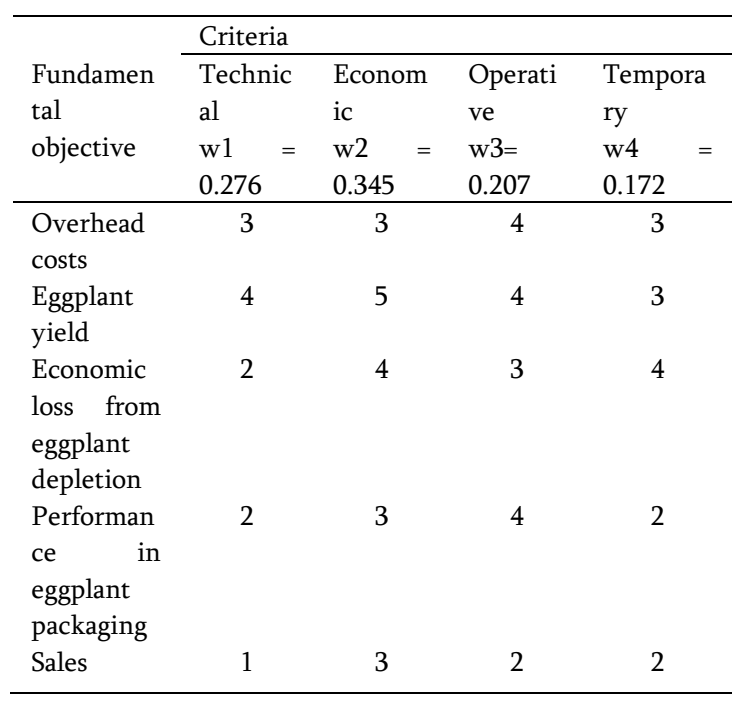

Source: Own elaboration. Notes: $w 1, w 2, w 3$, and $w 4$ are the weights of the criteria. Values mean: 5) Highly feasible, 4) Very feasible, 3) Feasible, 2) Bit feasible, 1) Not feasible.

With data of Table 5 , the utility $u$ of each fundamental objective $a_{i} \in A ; i=1, \ldots, 5$ was computed as $u\left(a_{i}\right)=w_{1} g_{1}+w_{2} g_{2}+w_{3} g_{3}+w_{4} g_{4}$; where $a_{i}$ is the $i^{\text {th }}$ fundamental objective; $i=1, . ., 5$ and $w_{j}$ is the $j^{\text {th }}$ weight of the attribute ${ }^{g_{j}}$; $j=1, . ., 4$. Table 4 shows the utilities of each fundamental objective.

TABLE. 4 THE UTILITY OF EACH FUNDAMENTAL OBJECTIVE

\begin{tabular}{lc}
\hline Fundamental Objective & Utility \\
\hline Overhead costs & 0.212 \\
Eggplant yield & 0.273 \\
Economic loss from eggplant depletion & 0.208 \\
Performance in eggplant packaging & 0.177 \\
Sales & 0.129 \\
\hline
\end{tabular}

Source: Own elaboration. 
TABLE 5. LIST OF SOLUTION ALTERNATIVES

\begin{tabular}{|c|c|}
\hline $\begin{array}{l}\text { Fundamental } \\
\text { objective }\end{array}$ & Alternatives \\
\hline \multirow{8}{*}{ Overhead costs } & Eggplant production planning \\
\hline & $\begin{array}{l}\text { Improves yield per square meter in } \\
\text { the seedling transplant }\end{array}$ \\
\hline & $\begin{array}{l}\text { Planning and reduction of packing } \\
\text { maintenance times }\end{array}$ \\
\hline & $\begin{array}{l}\text { Reducing packaging equipment's } \\
\text { inactivity }\end{array}$ \\
\hline & $\begin{array}{l}\text { Better use of the equipment, rent of } \\
\text { packaging for other vegetables }\end{array}$ \\
\hline & $\begin{array}{l}\text { Financing with a preferential interest } \\
\text { rate }\end{array}$ \\
\hline & Get government support for \\
\hline & $\begin{array}{l}\text { investment in infrastructure, } \\
\text { equipment, machinery, among others }\end{array}$ \\
\hline \multirow{5}{*}{ Eggplant yield } & $\begin{array}{l}\text { Control of crop efficiency indicators } \\
\text { (water, temperature, plant growth) }\end{array}$ \\
\hline & $\begin{array}{l}\text { Acquire quality seeds (purity, age, } \\
\text { and maturation) }\end{array}$ \\
\hline & $\begin{array}{l}\text { Apply protected agriculture } \\
\text { technology }\end{array}$ \\
\hline & $\begin{array}{l}\text { Improve indicators of efficiency in } \\
\text { crops }\end{array}$ \\
\hline & $\begin{array}{l}\text { Transplant in appropriate conditions } \\
\text { (climate, soil) }\end{array}$ \\
\hline \multirow{4}{*}{$\begin{array}{l}\text { Economic loss } \\
\text { from eggplant } \\
\text { depletion }\end{array}$} & Sell waste as food for livestock \\
\hline & Increase the shelf life of eggplant \\
\hline & $\begin{array}{l}\text { Make compounds and pesticides from } \\
\text { eggplant }\end{array}$ \\
\hline & $\begin{array}{l}\text { Design new products derived from } \\
\text { the eggplant }\end{array}$ \\
\hline \multirow{5}{*}{$\begin{array}{l}\text { Performance in } \\
\text { eggplant } \\
\text { packaging }\end{array}$} & $\begin{array}{l}\text { Analyze the logistics performance } \\
\text { indicators }\end{array}$ \\
\hline & $\begin{array}{l}\text { Implement a manual of best practices } \\
\text { on handling and packaging }\end{array}$ \\
\hline & $\begin{array}{l}\text { Improve supervision in cutting and } \\
\text { handling of eggplant }\end{array}$ \\
\hline & Train staff in packing processes \\
\hline & $\begin{array}{l}\text { Improve working conditions in } \\
\text { housing and assigned tasks to workers }\end{array}$ \\
\hline \multirow{6}{*}{ Sales } & $\begin{array}{l}\text { Analyze the market to achieve } \\
\text { customer needs }\end{array}$ \\
\hline & $\begin{array}{l}\text { Opening new markets for fresh } \\
\text { eggplant }\end{array}$ \\
\hline & Diversification on fresh presentation \\
\hline & $\begin{array}{l}\text { Increase presence in the market in } \\
\text { high season }\end{array}$ \\
\hline & $\begin{array}{l}\text { Establish marketing contracts with } \\
\text { the distributor }\end{array}$ \\
\hline & $\begin{array}{l}\text { Analyze proposals with other } \\
\text { distributors. }\end{array}$ \\
\hline
\end{tabular}

Source: Own elaboration.
After applying VFT methodology to structure the problem and generate a set the alternatives, the objectives of this work ends, i.e., the crucial identification of the most prominent alternatives is a different process out of the article's scope. Nevertheless, as a preliminary exercise, the decision-maker identifies the preferred alternatives according to his preferences, experience, knowledge, and intuition.

TABLE 6. PRELIMINARY ALTERNATIVES IDENTIFIED BY THE DECISION-MAKER

\begin{tabular}{|c|c|}
\hline Alternative & Importance \\
\hline $\begin{array}{l}\text { Eggplant production } \\
\text { planning adapted to } \\
\text { the markets }\end{array}$ & $\begin{array}{l}\text { It is imperative to plan, sow, and } \\
\text { produce eggplant based on market } \\
\text { demand with the distributor's } \\
\text { information, which has market } \\
\text { trends. Moreover, the farm must } \\
\text { fulfill the signed contracts with its } \\
\text { distributor. }\end{array}$ \\
\hline $\begin{array}{l}\text { Improving yield per } \\
\text { square meter in the } \\
\text { seedling transplant }\end{array}$ & $\begin{array}{l}\text { It allows reducing the use of the } \\
\text { seed, greenhouse expenses, and a } \\
\text { possible increment in eggplant } \\
\text { production. }\end{array}$ \\
\hline $\begin{array}{l}\text { Apply protected } \\
\text { agriculture } \\
\text { technology }\end{array}$ & $\begin{array}{l}\text { Protected agricultural technology } \\
\text { reduces the phytosanitary risk } \\
\text { and controls environmental } \\
\text { factors to affect the product's } \\
\text { quality. }\end{array}$ \\
\hline $\begin{array}{l}\text { Increase the eggplant } \\
\text { shelf life }\end{array}$ & $\begin{array}{l}\text { It offers quality and flavor to } \\
\text { consumers. Also, it allows } \\
\text { exporting eggplant to more } \\
\text { distant markets. }\end{array}$ \\
\hline $\begin{array}{l}\text { Opening new } \\
\text { markets of fresh } \\
\text { eggplant }\end{array}$ & $\begin{array}{l}\text { It could lead to the farm obtaining } \\
\text { a more significant market share } \\
\text { and increase its economic benefit. }\end{array}$ \\
\hline $\begin{array}{l}\text { Diversification on a } \\
\text { fresh presentation }\end{array}$ & $\begin{array}{l}\text { It could be the farm to increase its } \\
\text { economic benefit and presence in } \\
\text { the market. It is an opportunity to } \\
\text { position eggplant in new markets } \\
\text { and achieve greater } \\
\text { competitiveness in the export } \\
\text { market. }\end{array}$ \\
\hline $\begin{array}{l}\text { Design new products } \\
\text { derived from } \\
\text { eggplant }\end{array}$ & $\begin{array}{l}\text { It allows using non-marketed } \\
\text { eggplant due to its export quality } \\
\text { conditions or price in the market. } \\
\text { This product can be oriented as } \\
\text { raw material to strengthen or } \\
\text { create new products from } \\
\text { different companies or be a } \\
\text { product for the final consumer. }\end{array}$ \\
\hline
\end{tabular}

Source: Own elaboration. 
Table 6 shows the preliminary alternatives (non-ordered) identified by the decisionmaker. This selection does not mean that such alternatives will be carried out without an in-depth analysis later. Also, the decision was not arbitrary, but it was supported by understanding the problem and knowledge of the decision-maker, where knowledge includes, as Young \& Milton (2011) points out, information, heuristics, theory and experience, non-minor elements in decision making. However, it is not recommended only to use experience, knowledge, and intuition to select the best alternatives. Instead, it should be carried out using, as noted by (Keeney, 1996), an alternativefocused thinking method such as AHP (Saaty, 1980), MAUT, TOPSIS (Hwang \& Yoon (1981), TODIM (Gomes \& Lima, 1991), etc. This type of methods starts with a set of alternatives, as the generated set of this work.

\section{CONCLUSIONS}

This work highlighted the importance of avoiding food loss in the agricultural sector since it has different environmental, economic, and social impacts. Food loss can reduce the companies' production capacity in subsequent seasons, impacting the economy of farmers and families that depend on the agricultural sector. We also demonstrated that to reduce food loss of farms, it is necessary to structure the problem to clarify their contexts and capabilities.

This study presented the eggplant loss problem in a horticultural farm. It showed how to apply the VFT methodology to structure such a problem and generate solution alternatives for it. VFT methodology is adequate to aid the decision-maker to understand, structure the problem, and create solution alternatives. Using VFT positively impacts the organization because it allows describing the organization's actual situation and guides the decision-maker in developing short and long-term strategic planning. Likewise, the decision-maker obtains greater knowledge of the context and skills to create alternatives and strategies in complex situations, which is an essential change in the organizational culture. Among others, the VFT methodology aligns the decision maker's objectives with the companies. There are requirements for the successful application of VFT; among others, the decision-maker should know the organization from operational, organizational, and financial levels; therefore, VFT can be used with decisionmakers because this is not always possible. Besides, the decision-maker must have time availability, openness, and confidence to issue their values. It is not easy for a farm's decision-maker to express the sales volumes, prices, and competitive advantages to third parties and recognize when something does not work correctly inside the farm. The latter was successful in this work because, during the VFT application process, the decisionmaker changed its perception about the farm and the eggplant loss problem with the results of VFT. For instance, the decisionmaker understood the relations between the objectives and the actions with the final version of the objectives network diagram. This generated confidence between the parties, despite the network diagram of objectives, was modified several times. Like the methodologies Strategic Options Development and Analysis (SODA) and Soft Systems Methodology (SSM), VFT can be used for individual and group decisionmaking problems, defining the problem's contextual framework. However, SODA is 
not oriented to identify stakeholders and define attributes; but both can identify criteria and develop alternatives. On the other hand, SSM has a low orientation to define attributes, but it has a moderate orientation to identify stakeholders and criteria and develop alternatives.

This application allowed to confirm this type of methodology is necessary to support decision making because decision-makers tend to identify only alternatives that quickly come to mind. As pointed out before, decision-makers should not use only their experience, knowledge, and intuition to tackle the decision to select the best alternatives, as in the preliminary exercise done by the decision-maker. Instead, it is recommended to use alternative-focused thinking methods.

Future work must analyze and select the solution alternatives to develop courses of action to implement them. For the first part, it is recommended to use an AlternativeFocused Thinking method base on a multicriteria/multi-attribute decision support approach.

\section{ACKNOWLEDGMENTS}

This work was supported partially by the Mexican National Council of Science and Technology (CONACyT) [research project \#2015-01-162]. The authors gratefully acknowledge the decision-maker of the farm for his availability, openness, and trust with the development of this work.

\section{REFERENCIAS}

Alencar, L. H., Mota, C. M. de M., \& Alencar, M. H. (2011). The problem of disposing of plaster waste from building sites: Problem structuring based on value focus thinking methodology. Waste Management, 31(12), 2512-2521. https://doi.org/10.1016/J.WASMAN.2011.06.015
Barron, F. H., \& Barrett, B. E. (1996). The efficacy of SMARTER - simple multi-attribute rating technique extended to ranking. Acta Psychologica, 93(1-3), 23-36. https://doi.org/10.1016/0001-6918(96)00010-8

Beausang, C., Hall, C., \& Toma, L. (2017). Food waste and losses in primary production: Qualitative insights from horticulture. Resources, Conservation and Recycling, 126(January), 177-185.

https://doi.org/10.1016/j.resconrec.2017.07.042

CEC. (2017). Characterization and management of food loss and waste in North America. Retrieved from http://www3.cec.org/islandora/en/item/11772-

characterization-and-management-food-loss-and-wastein-north-america-en.pdf

CEC. (2019). Quantifying Food loss and waste and its impacts. Montreal, Quebec. Retrieved from http://www3.cec.org/islandora/en/item/11813-technicalreport-quantifying-food-loss-and-waste-and-its-impactsen.pdf

Edwards, W., \& Barron, F. H. (1994). SMARTS and SMARTER: Improved Simple Methods for Multiattribute Utility Measurement. Organizational Behavior and Human Decision Processes, 60(3), 306-325. https://doi.org/https://doi.org/10.1006/obhd.1994.1087

FAO. (2011). Global food losses and food waste - Extent, causes and prevention. Rome, Italy: FAO.

Gallo, M., Naviglio, D., \& Ferrara, L. (2014). Nasunin, an Antioxidant anthocyanin from eggplant peels, as natural dye to avoid food allergies and intolerances. European Scientific Journal, 10(9), 1-11. https://doi.org/10.19044/esj.2014.v10n9p\%p

Ghidelli, C., Mateos, M., Rojas-Argudo, C., \& Pérez-Gago, M. B. (2014). Extending the shelf life of fresh-cut eggplant with a soy protein-cysteine based edible coating and modified atmosphere packaging. Postharvest Biology and Technology, 95, 81-87. https://doi.org/https://doi.org/10.1016/j.postharvbio.2014. 04.007

GSS. (2017). State development plan 2017-2021 (In Spanish). Retrieved from https://sinaloa.gob.mx/uploads/2017/06/plan-estatal-dedesarrollo-sinaloa-2017-2021.pdf

Hodges, R. J., Buzby, J. C., \& Bennett, B. (2011). Postharvest losses and waste in developed and less developed countries: opportunities to improve resource use. The Journal of Agricultural Science, 149(S1), 37-45. https://doi.org/10.1017/S0021859610000936

INEGI. (2015). Intercensal survey 2015 - main results (In Spanish). Retrieved September 15, 2019, from https://www.inegi.org.mx/contenidos/programas/interce nsal/2015/doc/eic_2015_presentacion.pdf 


\section{Structuring and creating alternatives for the eggplant loss problem using the value-focused thinking methodology}

ITC. (2019a). List of exporters for the selected product. Product: 07 Edible vegetables and certain roots and tubers. Retrieved September 15, 2019, from https://www.trademap.org/tradestat/Country_SelProduct _TS.aspx?nvpm=1\%7C\%7C\%7C\%7C\%7C07\%7C\%7C\%7 C2\%7C1\%7C1\%7C2\%7C2\%7C1\%7C2\%7C1\%7C1

ITC. (2019b). List of importing markets for the product exported by Mexico in 2018. Product: 070930 Fresh or chilled aubergines "eggplants." Retrieved September 15, 2019 ,

from https://www.trademap.org/Country_SelProductCountry. aspx?nvpm=1\%7C484\%7C\%7C\%7C\%7C070930\%7C\%7C \%7C6\%7C1\%7C1\%7C2\%7C1\%7C\%7C2\%7C1\%7C1

Karjalainen, T. P., Marttunen, M., Sarkki, S., \& Rytkönen, A.M. (2013). Integrating ecosystem services into environmental impact assessment: An analyticdeliberative approach. Environmental Impact Assessment Review, 40, 54-64. https://doi.org/https://doi.org/10.1016/j.eiar.2012.12.001

Keeney, G. L., \& Von Winterfeldt, D. (2010). Identifying and structuring the objectives of terrorists. Risk Analysis, 30(12), 1803-1816. https://doi.org/10.1111/j.15396924.2010.01472.x

Keeney, R. L. (1996). Value-focused thinking: a path to creative decision-making. London, England: Harvard University Press. https://doi.org/10.1016/s00246301(97)80025-8

Keeney, R. L. (2013). Identifying, prioritizing, and using multiple objectives. EURO J Decis Process, 1, 45-67. https://doi.org/10.1007/s40070-013-0002-9

Kenney, R. L., \& Raiffa, H. (1976). Decisions with multiple objectives: preferences and value tradeoffs. New York: Wiley.

Llave, Y., Takemori, K., Fukuoka, M., Takemori, T., Tomita, H., \& Sakai, N. (2016). Mathematical modeling of shrinkage deformation in eggplant undergoing simultaneous heat and mass transfer during convectionoven roasting. Journal of Food Engineering, 178, 124-136. https://doi.org/10.1016/J.JFOODENG.2016.01.013

May, J., Dhillon, G., \& Caldeira, M. (2013). Defining valuebased objectives for ERP systems planning. Decis. Support Syst., 55(1), 98-109. https://doi.org/10.1016/j.dss.2012.12.036

Meyer, R. S., Bamshad, M., Fuller, D. Q., \& Litt, A. (2014). Comparing medicinal uses of eggplant and related solanaceae in China, India, and the Philippines suggests the independent development of uses, cultural diffusion, and recent species substitutions. Economic Botany, 68(2), 137-152. https://doi.org/10.1007/s12231-014-9267-6

Mustajoki, J., Saarikoski, H., Marttunen, M., Ahtikoski, A., Hallikainen, V., Helle, T., ... Ylisirniö, A.-L. (2011). Use of decision analysis interviews to support the sustainable use of the forests in Finnish Upper Lapland. Journal of
Environmental Management, 92(6), 1550-1563. https://doi.org/10.1016/J.JENVMAN.2011.01.007

Papargyropoulou, E., Lozano, R., Steinberger, J., Wright, N., \& Ujang, Z. bin. (2014). The food waste hierarchy as a framework for the management of food surplus and food waste. Journal of Cleaner Production, 76, 106-115. https://doi.org/10.1016/J.JCLEPRO.2014.04.020

Principato, L., Ruini, L., Guidi, M., \& Secondi, L. (2019). Adopting the circular economy approach on food loss and waste: The case of Italian pasta production. Resources, Conservation and Recycling, 144(December 2018), 82-89. https://doi.org/10.1016/j.resconrec.2019.01.025

Redlingshöfer, B., Coudurier, B., \& Georget, M. (2017). Quantifying food loss during primary production and processing in France. Journal of Cleaner Production, 164, 703-714. https://doi.org/10.1016/j.jclepro.2017.06.173

Roy, B., \& Bouyssou, D. (1993). Aide multicritère à la décision : méthodes et cas. Paris: Economica.

SADER. (2019). Agri-Food Atlas 2012-2018. Retrieved from https://nube.siap.gob.mx/gobmx_publicaciones_siap/pag/ 2018/Atlas-Agroalimentario-2018

Secretary of Economy. (2019). Tariff information system via internet. 0709.30 - Eggplants (In Spanish). Retrieved September 15, 2019, from http://www.economiasnci.gob.mx/

Selart, M., \& Johansen, S. T. (2011). Understanding the role of value-focused thinking in idea management. Creativity and Innovation Management, 20(3), 196-206. https://doi.org/10.1111/j.1467-8691.2011.00602.x

Sheng, H., Siau, K., \& Nah, F. F.-H. (2010). Understanding the values of mobile technology in education: a value-focused thinking approach. SIGMIS Database, 41(2), 25-44. https://doi.org/10.1145/1795377.1795380

Siau, K., \& Ling, M. (2017). Mobile collaboration support for virtual teams: the case of virtual information systems development teams. Journal of Database Management (JDM), 28(3), 48-69. https://doi.org/10.4018/JDM.2017070103

Siebert, J., \& Keeney, R. L. (2015). Creating more and better alternatives for decisions using objectives. Operations Research, 63(5), 1144-1158. https://doi.org/10.1287/opre.2015.1411

Thyberg, K. L., \& Tonjes, D. J. (2016). Drivers of food waste and their implications for sustainable policy development. Resources, Conservation and Recycling, 106, 110-123. https://doi.org/10.1016/J.RESCONREC.2015.11.016

UN. Transforming our world: The 2030 agenda for sustainable development, Pub. L. No. A/RES/70/1 (2015). United Nations. Retrieved from https://sustainabledevelopment.un.org/post2015/transfor mingourworld/publication 
Larreta Ramírez, Elsa Verónica, Gastélum Chavira, Diego Alonso, Leyva López, Juan Carlos, Ahumada Valenzuela, Omar

Von Neumann, J., \& Morgenstern, O. (1944). Theory of games and economic behaviour. New Jersey: Princeton University Press.
Wakiyama, T., Lenzen, M., Faturay, F., Geschke, A., Malik, A., Fry, J., \& Nansai, K. (2019). Responsibility for food loss from a regional supply-chain perspective. Resources, Conservation and Recycling, 146(April), 373-383. https://doi.org/10.1016/j.resconrec.2019.04.003

\section{Appendix A}

\section{Network of strategic, fundamental \& means-ends objectives in the horticultural company}

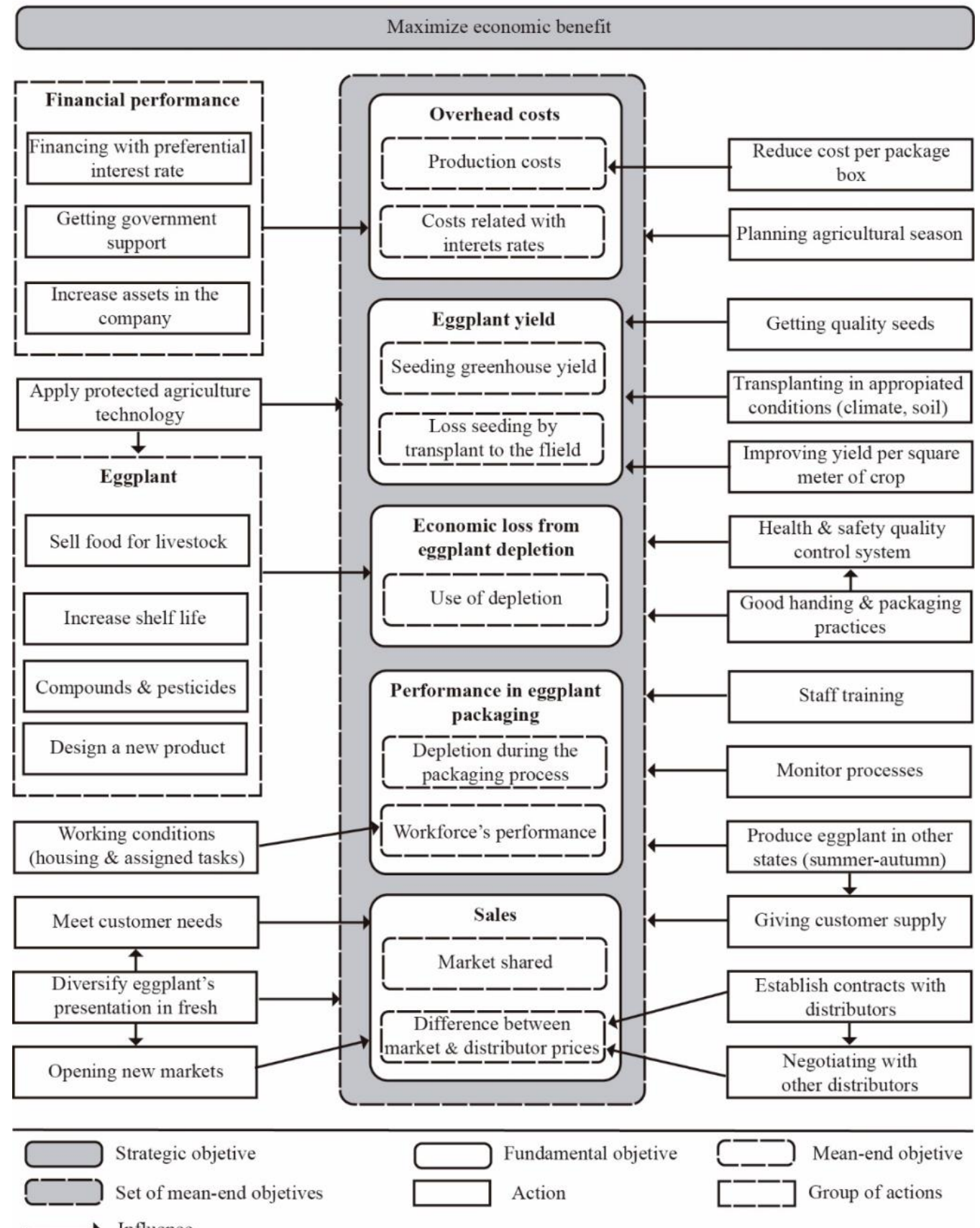

Source: Own elaboration 